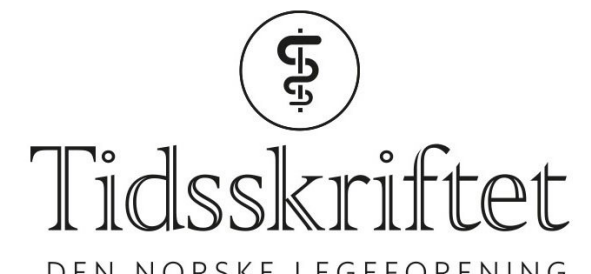

DEN NORSKE LEGEFORENING

\title{
- Jeg har drevet meg selv hardt
}

INTERVJU

CHARLOTTE LUNDE

E-post: charlottelunde@me.com

Hadde Gunhild Stordalen kunnet reise tilbake i tid, ville hun bedt den ti år yngre Gunhild om å være litt snillere mot seg selv.

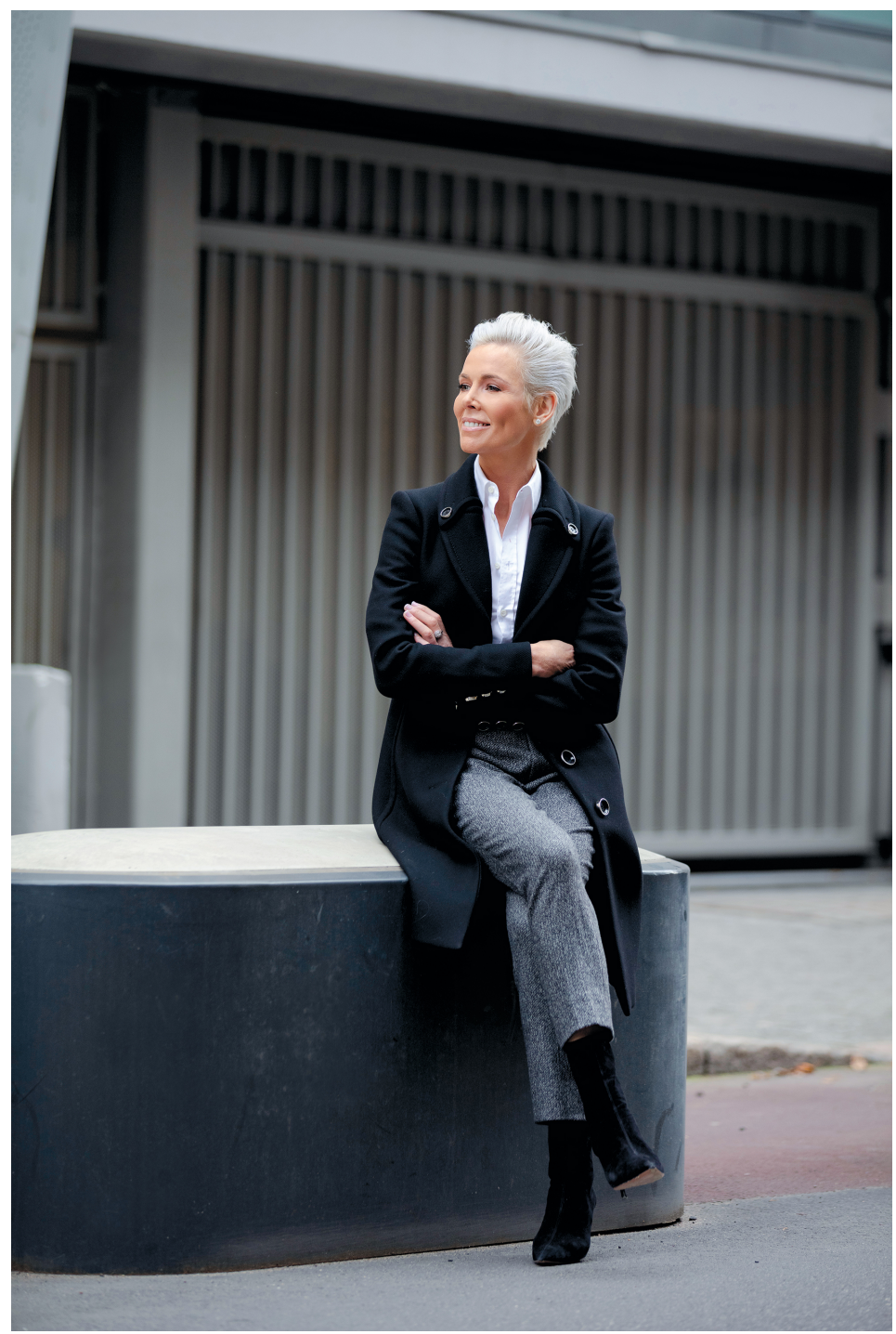

Alle foto: Christian Tunge

Hun har et åpent blikk og et par solide diamanter som gnistrer i ørene. Det korte håret er 
sølvfarget. Hun smiler.

- Jeg hadde ledd meg skakk om du hadde fortalt meg for ti år siden at jeg en dag kom til å løpe rundt og snakke om søvn, meditasjon og mat som medisin. Men det er jo den personlige reisen her.

Gunhild Stordalens personlige reise startet med et tydelig mål.

- Alle mine beste venner hadde fire bein. Hadde de to, snakker vi om fugler. Det var dyrehelse og dyrevelferd som engasjerte meg mest, forteller Gunhild og beskriver veien hun tok inn i miljøsaken.

\section{Et sjokk}

Klimaforkjemper, lege, forsker, tidligere modell, Petter Stordalens ekskone, miljøprisvinner, sklerodermipasient; mange roller til tross, det er som arbeidende styreleder i EAT Foundation hun drives fremover:

- Når du snakker om klima i et helseperspektiv, er det ufattelig mange flere som lytter. Helseargumentet er noe alle skjønner. Trump kommer aldri til å bry seg om miljø eller klima, men selv han kan ikke ignorere at mat nå dreper flere enn både alkohol, tobakk og narkotika.

Stordalen er fremoverlent når hun snakker. Hun står ikke lenger opp klokken 04 for å rekke en løpetur før jobb, men hun har fremdeles liten tid til å hvile når isen smelter under føttene på oss. Verdens matsystem står for en fjerdedel av klimagassutslippene. Det er blant annet dette organisasjonen EAT, som hun startet gjennom stiftelsen hun fikk i morgengave av eksmannen, jobber med å endre.

\section{Gunhild Stordalen}

Født januar 1979

Cand.med., Universitetet i Oslo 2007

Ph.d. Universitetet i Oslo 2010

Turnustjeneste Aker sykehus og Frogner Legesenter 2010-12

Styreleder og etablerer av Stordalen Foundation 2012

Etablerer EAT Initiative 2013

Direktør for EAT Forum 2013-d.d.

Mottok prisen Young Global Leader, World Economic Forum 2015

Mottok Global Leadership Award, United Nations Foundation 2019

EATs lokaler ligger midt i Oslo sentrum. Siden starten i 2013 har organisasjonen vokst fra tre frivillige til over 30 ansatte miljøentusiaster fra hele verden. En oransje logo lyser i store 3Dbokstaver i resepsjonen. På vei inn til Gunhild Stordalens kontor passerer vi et gigantfotografi av en løve. Den titter ned på oss med et nærmest anklagende blikk. På skrivebordet ligger boken Why Capitalism is wrong.

- Du mener kapitalismen har feilet?

- Ja, det gjør jeg. Vi trenger en ny og mer bærekraftig kapitalisme. Historien har vist oss at når kapitalismen slippes helt fri, og kortsiktig grådighet får bestemme, kan det gå veldig galt. Kapitalismen har ført til økende forskjeller, og når den ikke reguleres godt nok, blir resultatet ofte at det drives rovdrift på naturressurser og miljø.

- Men EAT ville vel ikke eksistert uten kapitalismen?

- Det kan du si, men jeg mener det er en forslitt kritikk. Det går an å ha to tanker i hodet samtidig. Man kan tjene penger, men samtidig bidra til samfunnsnyttige formål. Og EAT handler nettopp om å bringe sammen myndigheter, organisasjoner og næringslivet slik at 
vi kan løse utfordringene i fellesskap. Jeg er overbevist om at de selskapene som evner å ta inn over seg sitt samfunnsansvar og gjøre det til en integrert del av sin forretningsstrategi, er fremtidens vinnere.

Men la oss gå tilbake til begynnelsen. Der miljøinteressen startet.

- I arbeidsuka på ungdomsskolen jobbet jeg med en stordyrsveterinær og fikk se industrielt landbruk på nært hold. Det var en nesten sjokkartet opplevelse. Jeg hadde forestilt meg at jeg skulle være dyrenes lege, men det var så mange problematiske sider. Skulle jeg jobbe med dyrevelferd, måtte jeg bruke kreftene på en annen måte, oppsummerer hun.

Det måtte bli medisin.

- Mamma var lege. Onkelen min var lege, og jeg var jo allerede da litt miljøskadet,

konkluderer hun

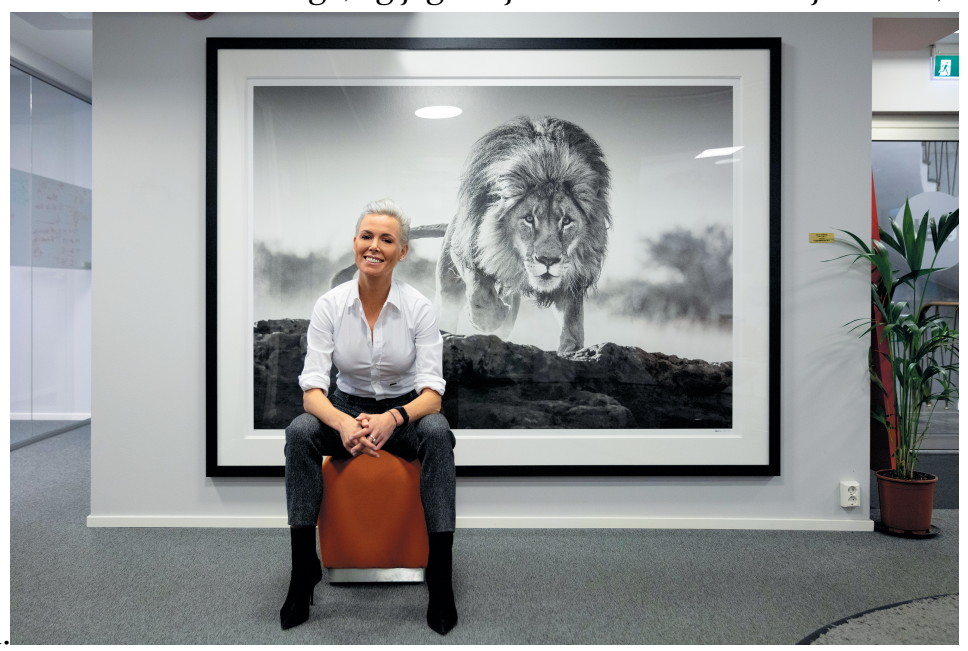

\section{Mareritt}

1980-årenes miljøkamp rullet over tv-skjermene. Aktivister lenket seg fast for saken, men ble arrestert og kjørt vekk. Miljøtrusselen gjorde inntrykk på en liten førsteklassing fra Muggerud utenfor Kongsberg.

- Mamma satt og trøstet meg hver eneste natt fordi jeg hadde mareritt om hull i ozonlaget, forurensningen som ødela planeten og alle dyrene som døde. Jeg hadde masse angst, men mamma sa til meg: «Gunhild, dette er menneskeskapte problemer, og det betyr også at menneskeheten kan løse det. Ingen kan gjøre alt, man alle kan gjøre noe.» Den miljøbevisste syvåringen tenkte for seg selv: «Ok, da skal i hvert fall jeg gjøre det jeg kan med å bidra til en bedre kurs for verden.»

Jeg har alltid tenkt at målene man setter seg skal være som fjell: høye og synlige

Inspirert av Gro Harlem Brundtland og en mamma i Leger mot atomvåpen hadde hun sett at verden lyttet til leger.

- Jeg måtte få meg en akademisk plattform.

Det gjorde hun. En solid en også. Etter embedseksamen ble det osteoporosestudier og doktorgrad i ortopedisk patologi. For en praktiker var det likevel en prøvelse å gå på forskerlinjen.

- Jeg syntes jo at forskning egentlig var gørrkjedelig. Jeg elsket å jobbe på ambulansen og være hands-on. Derfra til forskningslabben var det jo et sprik. Jeg tenkte likevel at det å få innblikk i forskningsarbeid er viktig. Det ville gi meg et fortrinn i forhold til det jeg ville videre.

Parallelt med doktorgraden gikk hun inn i styret til Nordic Choice. Her gikk det opp for henne at opptil $70 \%$ av hotellbransjens miljøavtrykk stammet fra mat og drikke. Dermed begynte hun å google hva slags forskning som var gjort på sunn mat og bærekraftig matforbruk. Det viste seg å være ingenting. Det ble starten på EAT - en forskningsbasert 
plattform for å samle aktører fra akademia, næringsliv, politikk og sivilsamfunn. I samarbeid med Lancet-redaktør Richard Horton satte hun like godt sammen et forskningsteam på 37 uavhengige eksperter for å skrive en rapport om temaet. Den ble lagt frem januar 2019 .

- I rapporten stilte man det spørsmålet som gjorde at jeg startet EAT: Hvordan skal vi produsere nok sunn mat til nesten ti milliarder mennesker på en måte som ikke ødelegger planeten?

\section{Høye fjell}

- Du er veldig målrettet?

Gunhild ser pliktskyldig ut. Hun ler nesten litt unnskyldende.

- Ja, det er det nok mange som er enig i. Jeg hadde en veldig klar plan fra jeg var tenåring, men så ble den planen veldig annerledes. Jeg har alltid tenkt at målene man setter seg skal være som fjell: høye og synlige. Så er det ikke alltid at man havner på det fjellet man har planlagt, men man kan komme på et annet fjell som kanskje er like spennende.

- Du reorienterte deg?

- Jeg visste hele tiden at det jeg hadde å bidra med, ville jeg bruke på best mulig måte for å skape en bedre verden, men jeg visste ikke helt hvordan. Jeg tenkte ikke så veldig mye på det mens jeg studerte, men mot slutten av studiet begynte klimainteressen å våkne igjen. Jeg savnet et fokus på forebygging. Det gjelder jo ikke bare i medisinen. Det gjelder overalt. Vi er et veldig reaktivt samfunn, påpeker 40-åringen. Hun husker likevel godt sin egen holdning til forebyggende medisin da hun studerte:

- Det mest usexy var jo forebyggende medisin. Det var det ingen som var opptatt av. Alle, inkludert meg selv, ville bli kirurger og kardiologer og jobbe med det vi tenkte var de viktige tingene. Det jeg likte best gjennom studiet, var jo arbeidet på ambulansen. Da følte jeg at jeg gjorde en forskjell.

Jeg hadde ikke kunnet tenke på de store systemproblemene hvis jeg hadde vært en trebarnsmor med to jobber og dårlig råd

- Men dette endret seg?

Hun stopper litt opp. Leter litt mer for å finne ordene.

- Ja, gjennom den veien som livet lot meg ta etter hvert. Jeg har ufattelig stor respekt for det kliniske arbeidet. Vi trenger fortsatt å bli bedre på diagnostikk og behandling og pasientoppfølging, men vi må samtidig øke oppmerksomheten på det å forebygge. Leger og helsepersonell må også jobbe for å hindre at pasientene i det hele tatt banker på døra til sykehuset eller legekontoret.

\section{Sosial ulikhet}

Biografien hennes, Det store bildet, var blant fjorårets mest solgte bøker. Her beskrives reisen fra en landlig oppvekst på Muggerud til maktens sentrum i den globale klimakampen. Vi får også den dramatiske historien om den dødelige sykdommen og forholdet til eksmannen. Hadde Gunhild skrevet boken alene, uten medforfatter Jonas Forsang, hadde den derimot vært et rent miljømanifest.

- Er du litt usentimental?

- Jeg liker å tro at jeg er rasjonell. Jeg er opptatt av å ta tak i roten til problemene, ikke bare sette plaster på og prøve å håndtere symptomene. Det å redde liv her og nå er viktig, men skal vi endre systemer, må vi se de store linjene. Man må heve blikket og jobbe langsiktig med de underliggende problemene i et samfunn. 


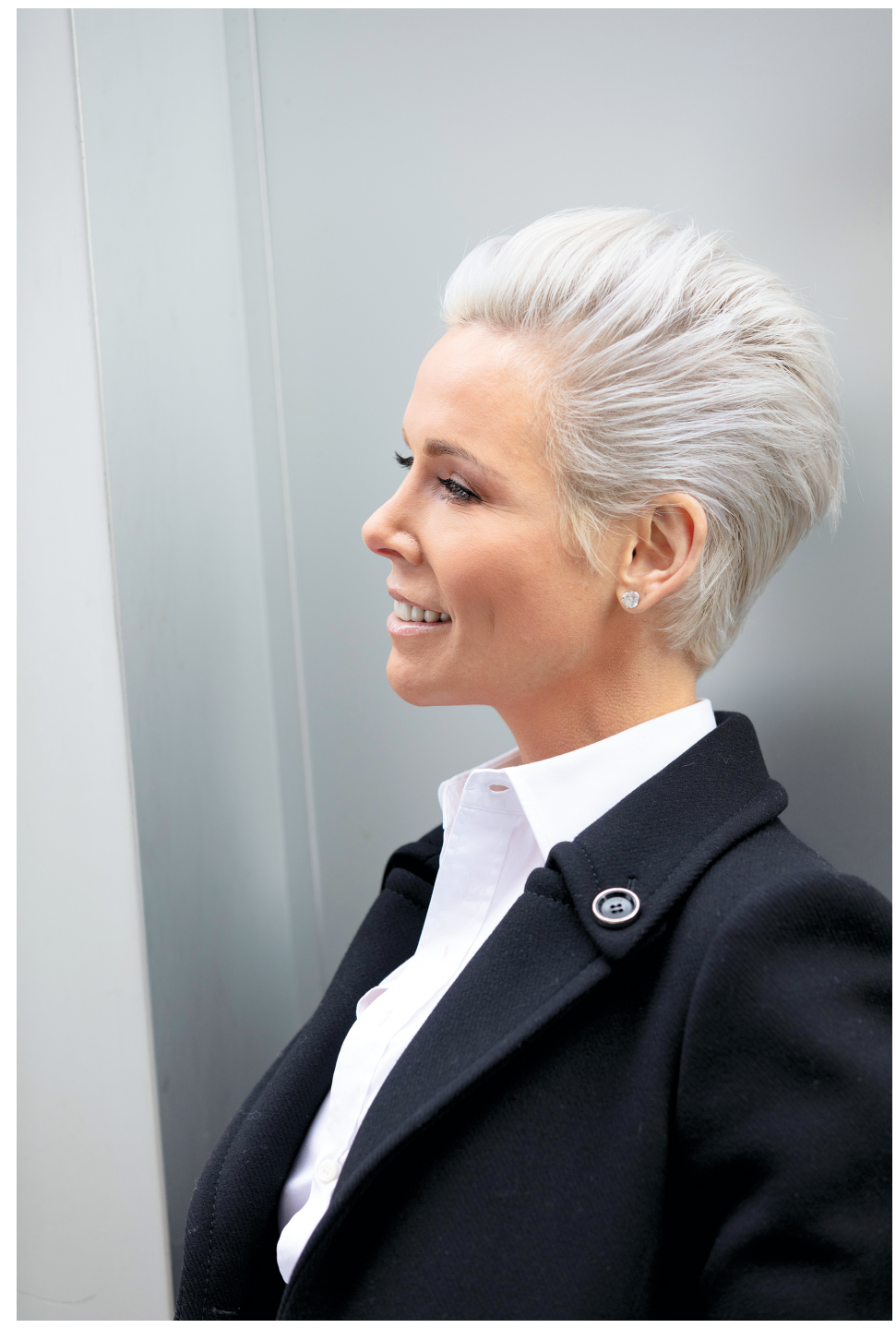

- Det er lett å bli imponert over styrken din. Tenker du at vi lever i en offerkultur?

- Det kan kanskje stemme, men jeg har vært utrolig heldig. Jeg aner ikke hvordan det hadde vært hvis jeg ikke hadde møtt Petter. Jeg hadde ikke kunnet tenke på de store systemproblemene hvis jeg hadde vært en trebarnsmor med to jobber og dårlig råd. Vi kan snakke om offerkultur, men det er like viktig å snakke om de sosiale driverne av ulikhet og dårlig helse og hvorfor folk tar de valgene de gjør. Før det blir lett å velge rett, kan vi ikke forvente at folk tar de rette valgene. Vi lever i et toksisk matmiljø. Du må hele tiden kjempe for å ta de riktige valgene. Vi har modernisert oss vekk fra naturen og sitter foran skjermene våre, disconnected fra oss selv.

Før det blir lett å velge rett, kan vi ikke forvente at folk tar de rette valgene

- Hvordan jobber du med dette selv?

- Jeg fikk en oppvåkning. Jeg har nok alltid vært sånn at alt skulle vært gjort helst før lunsj.

- Er du litt tvangspreget?

- Veldig! Tvang med stor T. Siden jeg var liten, har jeg hatt dårlig tid og følt at det hastet, at vi måtte gjøre mer. Sitte ned å slappe av har jeg aldri vært god på. Jeg har jo vært overstressa også. Alt det med sykdommen, og det jeg har hatt å tenke på. Samtidig som jeg prøvde å bygge en global organisasjon. Jeg orket ikke å forholde meg til det. Så jeg tok noen valg. Jeg kunne tatt en doktorgrad på sklerodermi, men bestemte meg for å overlate det til de som kan det. Jeg får heller tenke på hva jeg kan gjøre der jeg er. Jeg tenkte før jeg ble syk at jeg hadde 50 yrkesaktive år på å gjøre en forskjell, men nå tar jeg ingenting for gitt lenger. 


\section{Hvilepuls}

Omsorgen for miljøet har også gitt resultater. Nylig fikk hun en ny pris for sitt engasjement, "The global leadership award», og FNs generalsekretær har meddelt at FN vil arrangere Food Systems Summit allerede i 2021. Gjennom EAT-samarbeidet har også 14 storbyer rundt om i verden annonsert at de vil implementere EAT/Lancet-målene innen 2030. Mye har hun fått til, men egenomsorgen har ikke alltid vært like god.

- Hadde jeg visst det jeg vet i dag, hadde jeg kanskje ikke blitt så syk. Jeg har jo vært slem med meg selv. Jeg har presset meg over grensen. Jeg tenkte at søvn bare var tull. Ligge på ryggen i åtte timer når jeg kunne jobbe: hvorfor skulle jeg det? Jeg har vært stolt av at jeg bare sov fem timer i døgnet. Men så møtte jeg meg selv i døra i fjor vår og kjente at jeg ikke lenger husket hva hvilepuls var. Jeg sendte mailer på natten om ting jeg ikke hadde rukket gjennom dagen. Det gikk så fort at kroppen bare sa stopp.

Kursendringen skjedde både etter langvarig masing fra eksmannen, men også etter samtale med en kollega i EAT-nettverket.

- Mark Wilson, en internasjonal toppleder som sitter i rådgivningsgruppen vår, er blitt en god venn. Han har en ekstremt travel arbeidshverdag. «Hvordan i all verden klarer du å holde ut i det tempoet?» spurte jeg. Han sa bare et ord: «meditasjon». Jeg bare "What?!». New age-tull, tenkte jeg.

På Wilsons oppfordring tok hun et kurs.

- Det var en oppvåkning. Jeg har meditert hver dag siden. Jeg kommer aldri til å slutte. Hvis ikke du har det bra med deg selv, er det vanskelig å gjøre noe bra for andre.

\section{Karbonavtrykk}

Men selv om Gunhild Stordalen har lært seg å ta bedre vare på seg selv, er det fremdeles vanskelig å holde igjen engasjementet.

- Jeg bruker fremdeles all min våkne tid på å jobbe med EAT og har problemer med å akseptere at jeg har mindre kapasitet. Jeg reiser på en måte som verken er bærekraftig for meg eller planeten, men vi kunne ikke fått til dette dersom vi bare hadde sendt mailer og hatt videokonferanser. Vi karbonkompenserer alle reiser, men det å møte mennesker og samle dem for å få til samarbeid og koalisjoner, det finnes dessverre ingen teknologi per i dag som kan erstatte akkurat det.

- Hvis vennene dine skulle beskrive deg, hva ville de sagt?

- Veldig engasjert, ganske ensporet, men til å stole på. Jeg har ikke mye tid til å være sammen med venner eller familie, men jeg er der når det gjelder eller smeller, sier Gunhild.

Før jul ble det kjent at hun og eksmannen Petter Stordalen går fra hverandre. Det kommer ikke til å påvirke innsatsen i EAT.

- Jeg kommer selvfølgelig til å fortsette det viktige arbeidet med EAT. Petter og jeg har hatt fantastisk fine år sammen, og jeg har mye å takke ham for. Vi har stått side om side i ekstreme opp- og nedturer, som gjør at vi alltid vil ha et helt unikt forhold. Vi har sammen funnet ut at vi ønsker tid til å gjøre det vi brenner for, hver for oss. Vi er fortsatt hverandres beste venner og støttespillere.

Hvis ikke du har det bra med deg selv, er det vanskelig å gjøre noe bra for andre

- Men faller du aldri sammen og blir lei?

- Jo, det gjør jeg. Dette året har vært det verste i mitt 4o-årige liv. Jeg fikk en infeksjon i fjor sommer som ingen fant ut av, og var innlagt frem og tilbake gjennom våren. Ingenting hjalp. Jeg måtte bare delegere alt arbeidet til det fantastiske teamet mitt. Da tenkte jeg: Får jeg ikke jobbet med det jeg lever for, jobbet for å bidra, hva er egentlig vitsen med at jeg lager et så høyt karbonavtrykk på planeten? 
Nå er hun infeksjonsfri, har sluttet med immundempende medisiner og ser lyst på fremtiden. Og hun ser at arbeidet nytter.

- Du tenker at det er håp for miljøet?

- Jeg er overbevist om at det er håp. Jeg er ihuga optimist. Setter du deg ned og tenker at det går til helvete, så er det jo fort det som skjer. Tro kan flytte fjell. Når man tror at noe er mulig, blir det også mulig. Men vi må samarbeide, få til en global dugnad. Vi har forskning som viser at vi kan klare det, men vi har dårlig tid.

Publisert: 10. januar 2020. Tidsskr Nor Legeforen. DOI: 10.4045/tidsskr.19.08oo

(C) Tidsskrift for Den norske legeforening 2020. Lastet ned fra tidsskriftet.no 